\title{
Effect of a homofermentative lactic acid bacteria additive on the quality of sugar-beet pulp silage and animal response of dairy cows with restricted access to pasture
}

\author{
Rubén Pulido $^{1 *}$, Eduardo García ${ }^{1}$, Ignacio Beltrán ${ }^{2}$, José Daza $^{3}$, Juan Keim $^{4}$, and Ismael Castillo ${ }^{5}$ \\ ${ }^{1}$ Universidad Austral de Chile, Facultad de Ciencias Veterinarias, Casilla 567, Valdivia, Chile. \\ *Corresponding author (rpulido@uach.cl). \\ 2Instituto de Investigaciones Agropecuarias, INIA Remehue, Casilla 24-0, Osorno, Chile. \\ ${ }^{3}$ Instituto de Investigaciones Agropecuarias, INIA Tamel Aike, Casilla 296, Coyhaique, Chile. \\ ${ }^{4}$ Universidad Austral de Chile, Facultad de Ciencias Agrarias, Casilla 567, Valdivia, Chile. \\ ${ }^{5}$ Empresas Iansa, km 687 Ruta 5 Sur, Quepe, La Araucanía, Chile.
}

Received: 10 December 2019; Accepted: 6 February 2020; doi:10.4067/S0718-58392020000200234

\begin{abstract}
Sugar-beet (Beta vulgaris L. subsp. vulgaris) pulp is a valuable by-product from the manufacture of beet sugar fresh which is normally preserved in the form of silage. The aim of the present research was to evaluate the effect of adding a homofermentative lactic acid bacteria silage additive during the ensiling period on fermentation and quality of sugar-beet (SB) pulp silage and the animal performance of dairy cows given restricted daily access to pasture. Twelve Holstein $\times$ Friesian crossbred cows were assigned to two groups according to milk yield, body weight, days in milk, parity and body condition score. Groups were randomly allocated to two treatments: silage of SB pulp without additive (control diet, SB) and silage of SB pulp with additive (SB+additive). The experiment was carried out in two periods of $28 \mathrm{~d}$ each. Once finished each period, cows were crossed for treatments. Chemical composition of SB silage was modified by the additive: Neutral detergent fiber $(41.8 \%$ vs. $45.7 \% \mathrm{DM})$ and metabolizable energy $\left(2.54 v s .2 .55 \mathrm{Mcal} \mathrm{kg}^{-1} \mathrm{DM}\right)$ were greater and butyrate lower ( 0.34 vs. 4.10 $\left.\mathrm{mmol} \mathrm{L}^{-1}\right)$ for SB+additive compared with SB. However, milk production (24.6 and $\left.25.2 \mathrm{~kg} \mathrm{~d}^{-1}\right)$ and composition were not affected $(P>0.05)$ by treatments. Similarly, rumen volatile fatty acids were similar between treatments. In conclusion, the use of homofermentative lactic acid additive on SB silage modified the chemical composition of silage and reduced the pasture intake, however, no changes in milk production and composition were detected.
\end{abstract}

Key words: Beta vulgaris subsp. vulgaris, milk production, rumen fermentation, silage additive.

\section{INTRODUCTION}

In grazing-based dairy systems, variations in herbage growth rate and nutrient composition occur, causing herbage to be insufficient to meet the animal requirements during some periods such as winter and summer (Dillon, 2006). Restricting access time to pasture can be used as a management tool to increase grazing efficiency and pasture utilization (Chilibroste et al., 2007; Gregorini, 2012). Restricting herbage allowance or access time to pasture reduces herbage DM intake and milk production by dairy cows (Mattiauda et al., 2013), therefore it is necessary to provide supplementary feeds to meet the nutritional requirements of the milking herd (Peyraud and Delagarde, 2011). Supplementation with concentrates, silages, forage crops and/or by-products are common practices to improve nutritional status, and thereby milk yield in grazing dairy systems. 
Feeding sugar-beet (Beta vulgaris L. subsp. vulgaris) (SB) pulp by-products is a viable option to improve sustainability of dairy production systems by decreasing the dietary proportion of human edible products (Ertl et al., 2015). Sugarbeet pulp is common ingredient in concentrate of dairy cows in many parts of the world, serving as an energy source, and offering several advantages over the traditional high energy grains that are used in dairy cattle feeding programs (Münnich et al., 2017).

Sugar-beet pulp is available as either a wet (pressed shreds) and/or ensiled as a storage method. Because drying is an energy- and cost-intensive procedure, ensiling of pressed pulp has become a popular method of preservation in Europe (Weber et al., 2003). Dolezal et al. (2005) reported that ensiling SB pulp with a low DM content (15\%-18\%), increases the risk of undesired fermentation associated with increased production of volatile fatty acids (VFA), especially acetic and butyric acids, and alcohol. Many experiments have been made to find the best way to ensile SB pulp reducing losses during fermentation process. However, information available in the literature is less abundant and therefore less conclusive when sugar-beet pulp silage is preserved in the form of plastic bag silos. For decades, producers have had a wide variety of silage additives available to assist in forage preservation (Muck et al., 2018). Addition of silage additives could restrict and reduce fermentation, reducing DM losses from fermentation (Borreani et al., 2018). In addition, their main functions are either increase nutritional value of silage or improve fermentation so that storage losses are reduced.

It has been shown that in grazing systems the type and quality of silage can affect pasture consumption and therefore milk production responses (Ruiz-Albarrán et al., 2016). To the best of our knowledge, there is scarce information about beet pulp silage supplementation in grazing dairy cows. Thus, the aim of the present research was to evaluate the effect of adding a homofermentative lactic acid bacteria (LAB) silage-additive during the ensiling period on fermentation and quality of sugar-beet pulp silage and the animal performance of dairy cows given restricted daily access to pasture.

\section{MATERIALS AND METHODS}

\section{Experimental site and design}

All procedures in this study agreed with the Animal Welfare Committee of Universidad Austral de Chile. This trial was carried out at the Austral Agricultural Research Station of the Universidad Austral de Chile (39 $47^{\prime} \mathrm{S}, 73^{\circ} 14^{\prime}$ ' W) over a period of $56 \mathrm{~d}$ (10 October to 5 December 2018) in a change-over experimental design, with $21 \mathrm{~d}$ of adaptation to the diets and a 7-d measurement period. Once finished each period, cows were crossed for treatments.

The experiment was carried out on 6 ha grass pasture (59.5\% Lolium perenne L., 3.0\% Trifolium repens L., 2.2\% weed, and $35.3 \%$ dead material).

Twelve Holstein $\times$ Friesian crossbred cows were assigned to two groups according to milk yield $(28.5 \pm 2.1 \mathrm{~kg})$, body weight (BW) $(574.5 \pm 58.5 \mathrm{~kg})$, days in milk $(212.3 \pm 33.4 \mathrm{~d})$, parity $(4.8 \pm 1.6)$ and body condition score $(3.13 \pm 0.33)$. The groups were randomly allocated to two treatments: Silage of sugar-beet (Beta vulgaris L. subsp. vulgaris) pulp without additive (control diet, SB-additive), and silage of sugar-beet pulp with additive (SB+additive).

All cows received as diet a permanent pasture, SB pulp silage and a commercial concentrate (Table 1). The treatments were strip-grazed in the same paddock, separated by an electric fence and the cows were offered herbage allowance (measured at ground level) of $21 \mathrm{~kg} \mathrm{DM} \mathrm{cow}^{-1} \mathrm{~d}^{-1}$, which was allocated daily at 09:00 h, allowing them to graze for $8 \mathrm{~h}$. Areas provided for grazing were adjusted daily on a pre-grazing herbage mass (HM) basis, which was estimated from 100 measurements collected with a rising plate meter, and the corresponding herbage allowance. The difference between pregrazing and post-grazing HM for each grazed strip was assumed to be consumed by the cows and represented the pasture DM intake per hectare. In this study fresh SB pulp (pressed shreds) were ensiled in round bales. All cows were offered 6.25 $\mathrm{kg} \mathrm{DM} \mathrm{cow}{ }^{-1} \mathrm{~d}^{-1} \mathrm{SB}$ pulp silage (with or without additive) in feeding pens at 16:00 h, and $3.5 \mathrm{~kg} \mathrm{DM} \mathrm{cow}^{-1} \mathrm{~d}^{-1}$ concentrate together with silage in the cowshed. Water was always free access in the paddock and in the cowshed.

Sugar-beet silage was made from the same batch of sugar beets ('Crispina KWS', KWS SAAT SE, Einbeck, Germany). The silage additive contained colony-forming units of LAB: Lactococcus lactis SR354, Pediococcus pentosaceous P6, Enterococcus faecium M74, and Lactobacillus plantarum MiLab 393. 
Table 1. Chemical composition of herbage and supplements offered to dairy cows during the experiment.

\begin{tabular}{|c|c|c|c|c|c|c|c|c|}
\hline & Concentrate & $\mathrm{Sd}^{1}$ & SB-additive & SB+additive & $\mathrm{SEM}^{2}$ & P-value & Herbage & $\mathrm{Sd}$ \\
\hline $\mathrm{DM}, \%$ & 88.3 & 0.58 & 22.7 & 23.0 & 0.68 & 0.81 & 17.9 & 2.89 \\
\hline Ash & 7.31 & 0.33 & 6.81 & 6.60 & 0.22 & 0.46 & 8.81 & 1.33 \\
\hline $\mathrm{CP}, \% \mathrm{DM}$ & 10.3 & 0.03 & 9.1 & 8.7 & 0.19 & 0.19 & 20.1 & 2.42 \\
\hline NDF, \% DM & 20.4 & 0.04 & $41.8 \mathrm{~b}$ & $45.7 \mathrm{a}$ & 0.65 & 0.01 & 44.6 & 4.07 \\
\hline $\mathrm{ADF}, \% \mathrm{DM}$ & 7.53 & 0.16 & 24.4 & 23.5 & 0.29 & 0.12 & 22.1 & 1.15 \\
\hline ME, Mcal kg-1 DM & 2.97 & 0.01 & $2.54 \mathrm{~b}$ & $2.55 \mathrm{a}$ & 0.02 & 0.02 & 2.75 & 0.02 \\
\hline $\mathrm{NFC}, \% \mathrm{DM}$ & 58.4 & 0.43 & 41.9 & 38.8 & 0.89 & 0.07 & 24.6 & 7.94 \\
\hline $\mathrm{pH}$ & - & & 4.10 & 4.19 & 0.07 & 0.46 & - & \\
\hline $\mathrm{NH}_{3}-\mathrm{N}, \%$ & - & & 3.79 & 3.53 & 0.21 & 0.44 & - & \\
\hline Acetate, $\mathrm{mmol} \mathrm{L}^{-1}$ & - & & 1.89 & 1.92 & 0.27 & 0.94 & - & \\
\hline Butyrate, $\mathrm{mmol} \mathrm{L}^{-1}$ & - & & $4.10 \mathrm{a}$ & $0.34 \mathrm{~b}$ & 0.20 & $<0.01$ & - & \\
\hline
\end{tabular}

SB: Sugar-beet; CP: crude protein; NDF: neutral detergent fiber; ADF: acid detergent fiber; ME: metabolizable energy; NFC: non-fibrous carbohydrates; $\mathrm{NH}_{3}-\mathrm{N}$ : ammonia-N.

Means within a row with different letters differ $(P<0.05)$.

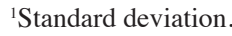

${ }^{2}$ Standard error of the mean.

\section{Measurements}

Pre- and post-grazing HM and herbage allowance were estimated using an electronic rising plate meter (RPM; Jenquip F150 Electronic Pasture Meter, Fielding, New Zealand). A total of 50 RPM measurements were taken pre- and postgrazing in each group grazing area, and HM DM estimated using a specific equation for spring pastures in southern Chile $(\mathrm{HM} \mathrm{kg} \mathrm{DM} \mathrm{ha-1}=\mathrm{RPM} \times 100+400)($ Canseco et al., 2007). Herbage samples were collected three times per week before grazing at $08: 30 \mathrm{~h}$ from herbage strips of each treatments to determine its nutritive value. Samples from herbage were collected using the hand-plucking technique. The weights of concentrate and SB pulp silage offered and refused were recorded daily to determine individual feed intake. Concentrate and silages were sampled during $3 \mathrm{~d}$ during sample weeks of the experiment. Herbage, concentrate and silages samples were frozen at $-20{ }^{\circ} \mathrm{C}$ and later freeze-dried and ground through $1 \mathrm{~mm}$ sieve (Willey Mill, 158 Arthur H, Thomas, Philadelphia, Pennsylvania, USA) and stored for chemical composition analysis. Samples were analyzed for DM, crude protein (CP), acid detergent fiber (ADF) and ash according to AOAC (1996). Neutral detergent fiber (NDF) content was determined by the method described by Van Soest et al. (1991). Metabolizable energy (ME) was estimated by regression using the digestible organic matter on DM basis (DOMD) and was determined in vitro (Tilley and Terry, 1963), according to Goering and Van Soest (1970). The pH and ammonia $\mathrm{N}\left(\mathrm{NH}_{3}-\mathrm{N}\right)$ in silage samples were derived by the method of AOAC (1996).

The cows were milked twice daily, and milk yields were recorded at each milking throughout the experimental period by an electronic device (MPC580 DeLaval, Tumba, Sweden). During the last week of each period, bulked morning and evening samples were analyzed for protein, fat and urea using infrared spectroscopy (Milko-scan, System 4300, Foss Electric, Hillerod, Denmark). Body weight was recorded twice a day after each milking using an automated system while cows were walking out of the milking shed. In addition, body condition score was recorded on a five-point scale (Ferguson et al., 1994).

For ruminal concentration of volatile fatty acids (VFA), rumen fluid was harvested by stomach tube (Flora Rumen Scoop; Prof-Products, Guelph, Ontario, Canada) before (15:00 h) and $7 \mathrm{~h}(22: 00 \mathrm{~h})$ after feeding sugar-beet pulp silage on days 4 and 5 of week for each period. Samples were strained through 4 layers of cheesecloth. A $10 \mathrm{~mL}$ sample was drawn off, mixed with $0.2 \mathrm{~mL} 50 \%$ (w/v) sulfuric acid, and stored at $-20^{\circ} \mathrm{C}$ pending determination of VFA. Rumen fluid was allowed to thaw for $16 \mathrm{~h}$ to $4{ }^{\circ} \mathrm{C}$, and then centrifuged at $10000 \times \mathrm{g}$ for $10 \mathrm{~min}$ at $4{ }^{\circ} \mathrm{C}$. Six milliliters of supernatant were drawn off and then centrifuged at $10000 \times \mathrm{g}$ for $10 \mathrm{~min}$ at $4{ }^{\circ} \mathrm{C}$. Thawed supernatant of rumen fluid samples were analyzed for VFA by gas chromatography as described by Tavendale et al. (2005).

\section{Statistical analysis}

Effect of treatments on milk production and milk composition were analyzed using a linear-mixed model (LMM) in SAS (SAS Institute, Cary, North Carolina, USA). The model included the fixed effects of treatment, period and their interaction, and the random effect of cow. Effect of treatments on rumen fermentation parameters were analyzed using 
a LMM in SAS software. The model included the fixed effects of treatment, period, time of day and the interactions between treatment and time of day. Model also included the random effect of cow.

Chemical composition of pasture was analyzed using the PROC MIXED in SAS. The model included the fixed effects of treatment, day of sampling and their interaction, and the random effect of plot. Comparison between treatments was carried out using the Tukey test. Results were considered significant at $P<0.05$ and tendency at $P<0.1$.

\section{RESULTS AND DISCUSSION}

Results of the chemical composition of the herbage, concentrate and silages eaten are presented in Table 1. Chemical composition was similar between silages $(P>0.05)$ for DM and $\mathrm{CP}$, although the silage with additive had a higher concentration of NDF and ME and are in accordance with values reported by Wyss et al. (2015) for SB pressed silages. The type of inoculant depends on the most common microbial problems affecting losses and quality. Where inhibiting clostridial activity is the primary issue, traditional homofermentative strains are the most beneficial, lowering $\mathrm{pH}$ more rapidly compared with an untreated silage (Borreani et al., 2018). In this study, only the lower butyrate content agrees with Kung and Muck (1997) in that the addition of facultative heterofermenters bacteria as additive usually results in lower $\mathrm{pH}$, acetic acid, butyric acid, and ammonia-N but higher in lactic acid content and exhibit better DM recovery compared with untreated silages. The lower butyric acid concentration in inoculated silage is in accordance with the metanalysis reported by Oliveira et al. (2017), who stated that reductions in butyrate in response to LAB inoculation is the most consistent and among the most important benefits. Results of pasture management and intake are presented in Table 2. Pre- and post-grazing HM were unaffected by treatment, averaging 2769 and $1659 \mathrm{~kg} \mathrm{DM} \mathrm{ha}^{-1}$, respectively. Pasture DM intake (DMI) was greater $(P<0.01)$ for treatment SB-additive compared with treatment SB+additive ( 8.45 and $8.20 \mathrm{~kg} \mathrm{DM} \mathrm{d}^{-1}$, respectively), but without any explanation for effect, similar than reported by metanalysis of Oliveira et al. (2017). In addition, there was a tendency $(P=0.08)$ to have a greater total DMI in treatment SB-additive compared with treatment SB+additive (17.6 and $16.9 \mathrm{~kg} \mathrm{DM} \mathrm{d}^{-1}$, respectively). Silage and concentrate DMI per cow were unaffected by treatment, averaging 5.50 and 3.5 $\mathrm{kg} \mathrm{DM} \mathrm{d}^{-1}$, respectively.

Results of milk production, milk composition, milk solids and body weight are presented in Table 3. Animal trials have also revealed that facultative heterofermenters bacteria have not only enhanced silage fermentation but also have improved milk production, daily gain, or feed efficiency (Weinberg and Muck, 1996; Oliveira et al., 2017). Milk production tended $(P=0.06)$ to be $2 \%$ greater $\left(+0.6 \mathrm{~kg} \mathrm{~d}^{-1}\right)$ for $\mathrm{SB}+$ additive than for SB-additive. A recent metanalysis of 31 lactating dairy cattle studies indicated that inoculation with homofermentative or facultative heterofermentative LAB increased raw milk production $\left(0.37 \mathrm{~kg} \mathrm{~d}^{-1} ; P<0.01\right)$, with only a trend for increased DMI and no effect on feed efficiency (Oliveira et al., 2017). It is known that improvements in animal performance from feeding inoculated silage are difficult to explain (Muck et al., 2018), therefore, in this study, the greater production could be explained by the better content of NDF, ME and rumen fermentation in treated silage group and probably by the inhibition of detrimental microbes and toxin production (Ellis et al., 2016), interaction of LAB with rumen microbes, and alteration of rumen fermentation (Weinberg et al., 2003). The greater NDF concentration of SB+additive is not necessarily related to poorer animal performance, as NDF of sugar-beet

Table 2. Grazing management and pasture, supplement and total intake of cows receiving a restricted daily access to pasture and supplemented with sugar-beet pulp silage with (SB+additive) and without (SB-additive) additive.

\begin{tabular}{|c|c|c|c|c|}
\hline & \multicolumn{2}{|c|}{ Treatment } & \multirow[b]{2}{*}{ SEM } & \multirow[b]{2}{*}{$P$ value } \\
\hline & SB-additive & SB+additive & & \\
\hline \multicolumn{5}{|c|}{ Pasture mass, $\mathrm{kg} \mathrm{DM} \mathrm{ha}^{-1}$} \\
\hline Pre-grazing & 2728 & 2809 & 114 & 0.26 \\
\hline Post-grazing & 1651 & 1666 & 43 & 0.77 \\
\hline \multicolumn{5}{|c|}{ Daily intake, $\mathrm{kg} \mathrm{DM} \mathrm{cow}^{-1}$} \\
\hline Pasture intake & $8.5 \mathrm{a}$ & $8.2 b$ & 0.02 & $<0.01$ \\
\hline Sugar beet silage & 5.7 & 5.3 & 0.26 & 0.23 \\
\hline Concentrate & 3.5 & 3.5 & - & - \\
\hline Total & 17.6 & 16.9 & 0.26 & 0.08 \\
\hline
\end{tabular}

Means within a row with different letters differ $(P<0.05)$.

SEM: Standard error of the mean. 
pulp is very low in lignin (Michel et al., 1988) and therefore highly digestible in the rumen (Kara, 2019). Loucka (2012) observed that sugar beet pulp silages without additives have a more of alcoholic fermentation and with higher proteolysis, factors that can negatively affect milk production. However, alcohol production and non-protein $\mathrm{N}$ were not assessed in our study, the greater butyric acid concentration in SB-additive suggests a more alcoholic fermentation and greater proteolysis, as it is associated with clostridial activity (Pahlow et al., 2003). In addition, the clostridial fermentation affects the hygienic quality of silage by creating conditions that permit an increase in the numbers of pathogenic organisms and their toxins (Flythe and Russell, 2004), and it is well known that mycotoxins have a negative impact on milk production responses (Rodriguez, 2014). Protein and fat concentration in milk were not affected by treatments, averaging 3.38\% and $3.86 \%$, respectively. In addition, despite differences in the concentration of butyric acid between silages, it did not affect the milk solids, urea content in milk and bodyweight between treatments $(P>0.05)$, as has happened in other studies.

The analysis of the effect of the additive on rumen total short chain fatty acids (SCFA, $\mathrm{mmol} \mathrm{L}^{-1}$ ) and SCFA composition (acetate, propionate and butyrate) are presented in Table 4. There is little information on the effects of ensilaged pressed SB pulp contained in dairy cow's ration. There were no effects of treatments on total or composition of SCFA, despite the greater ME and NDF when the additive was incorporated in the silage. Hall et al. (2015) noted that ruminal SCFA concentrations might not satisfactorily reflect treatment effects on ruminal fermentation without knowledge of rumen liquid volume, which was not analyzed in our study. It was observed a tendency to greater propionate proportion for SBadditive after $6 \mathrm{~h}$ of started the silage supplementation $(P=0.05)$, because of its numerical greater butyrate and acetate concentration at the same time, supporting the dilution in the propionate proportion.

A greater rumen SCFA -specifically butyrate concentration- has been associated with greater DMI (Seymour et al., 2005), however, in the current experiment the greater intake for SB-additive was not reflected in a greater SCFA rumen concentration. The lack of effect could be associated with the lower silage chemical composition compared with $\mathrm{SB}+$ additive (higher NDF and ME), suggesting that lower DMI was compensated by greater quality of nutrient intake, supporting the similar rumen fermentation parameters and milk production found in the current study.

Table 3. Milk production, milk composition, milk solids and bodyweight of grazing dairy cows receiving a restricted daily access to pasture and supplemented with sugar-beet pulp silage with (SB+additive) and without (SB-additive) additive.

\begin{tabular}{|c|c|c|c|c|}
\hline & \multicolumn{2}{|c|}{ Treatments } & \multirow[b]{2}{*}{ SEM } & \multirow[b]{2}{*}{$P$ value } \\
\hline & SB-additive & SB+additive & & \\
\hline Milk production, $\mathrm{kg} \mathrm{d}^{-1}$ & 24.6 & 25.2 & 0.60 & 0.06 \\
\hline Milk fat, $\%$ & 3.84 & 3.87 & 0.16 & 0.87 \\
\hline Milk protein, $\%$ & 3.42 & 3.33 & 0.08 & 0.22 \\
\hline Milk fat, $\mathrm{g} \mathrm{d}^{-1}$ & 914.3 & 971.2 & 42.5 & 0.31 \\
\hline Milk protein, $\mathrm{g} \mathrm{d}^{-1}$ & 834.1 & 831.9 & 18.3 & 0.92 \\
\hline Milk urea, $\mathrm{mg} \mathrm{L}^{-1}$ & 190.8 & 174.7 & 21.0 & 0.60 \\
\hline Live weight, kg & 592.0 & 592.0 & 12.6 & 0.98 \\
\hline
\end{tabular}

SEM: Standard error of the mean.

Table 4. Ruminal concentrations of acetate, butyrate, propionate and ammonia of grazing dairy cows receiving a restricted daily access to pasture and supplemented with sugar-beet pulp silage with (SB+additive) and without (SB-additive) additive.

\begin{tabular}{|c|c|c|c|c|c|c|c|c|c|}
\hline & \multicolumn{2}{|c|}{ Treatments } & \multirow[b]{2}{*}{ SEM } & \multicolumn{2}{|c|}{ Time of day } & \multirow[b]{2}{*}{ SEM } & \multicolumn{3}{|c|}{$P$ value } \\
\hline & SB-additive & SB+additive & & $\begin{array}{c}\text { Before } \\
\text { supplementation }\end{array}$ & $\begin{array}{c}\text { After } \\
\text { supplementation }\end{array}$ & & Trt & Time & Trt $\times$ Time \\
\hline \multicolumn{10}{|l|}{ SCFA, mmol L-1 } \\
\hline Acetate & 42.27 & 43.25 & 3.82 & 47.98 & 41.54 & 3.82 & 0.59 & 0.27 & 0.83 \\
\hline Propionate & 19.27 & 18.05 & 1.22 & $22.16 \mathrm{a}$ & $15.16 b$ & 1.22 & 0.51 & $<0.01$ & 0.26 \\
\hline Butyrate & 15.17 & 15.01 & 1.60 & $12.04 \mathrm{~b}$ & $18.14 \mathrm{a}$ & 1.6 & 0.94 & 0.03 & 0.42 \\
\hline Total SCFA & 76.24 & 80.71 & 5.88 & 88.28 & 68.67 & 5.88 & 0.61 & 0.05 & 0.73 \\
\hline \multicolumn{10}{|c|}{ SCFA, mol $100 \mathrm{~mol}^{-1}$} \\
\hline Acetate & 58.57 & 60.56 & 2.16 & 56.01 & 63.12 & 2.16 & 0.53 & 0.05 & 0.07 \\
\hline Propionate & 22.54 & 21.00 & 1.13 & $23.82 \mathrm{a}$ & $19.72 b$ & 1.13 & 0.37 & 0.03 & 0.05 \\
\hline Butyrate & 18.88 & 18.42 & 1.42 & 20.16 & 17.14 & 1.42 & 0.83 & 0.7 & 0.24 \\
\hline
\end{tabular}

Means within a row with different letters differ $(P<0.05)$.

SCFA: Total short chain fatty acids; SEM: Standard error of the mean; Trt: treatment. 


\section{CONCLUSIONS}

Under the condition of the current experiment, the homofermentative lactic acid bacteria silage-additive added during the ensiling period of the beet sugar silage increased the neutral detergent fiber and metabolizable energy content of the silage and reduced its butyrate concentration. Additionally, the use of this additive reduced the DM intake, however, milk production tended to be greater in the cows who received the silage with additive.

\section{REFERENCES}

AOAC. 1996. Official methods of analysis. $16^{\text {th }}$ ed. Association of Official Agricultural Chemists (AOAC) International, Gaithersburg, Maryland, USA.

Borreani, G., Tabacco, E., Schmidt, R.J., Holmes, B.J., and Muck, R.E. 2018. Silage review: Factors affecting dry matter and quality losses in silages. Journal of Dairy Science 101:3952-3979.

Canseco, C., Abarzúa, A., Parga, J., Teuber, N., Balocchi, O.A., Lopetegui, J., et al. 2007. Calidad nutritiva de las praderas. p. 51-67. In Teuber, N., Balocchi, O., and Parga, J. (eds.) Manejo del pastoreo. Imprenta América, Osorno, Chile.

Chilibroste, P., Soca, P., Mattiauda, D.A., Bentancur, O., and Robinson, P.H. 2007. Short term fasting as a tool to design effective grazing strategies for lactating dairy cattle: a review. Australian Journal of Experimental Agriculture 47:1075-1084.

Dillon, P. 2006. Achieving high dry-matter intake from pasture with grazing dairy cows. p. 1-26. In Elgersma, A., Dijkstra, J., and Tamminga, S. (eds.) Fresh herbage for dairy cattle. Springer, Dordrecht, The Netherlands.

Dolezal, P., Pyrochta, V., and Dolezal, J. 2005. Effects of chemical preservative and pressing of ensiled sugar-beet pulp on the quality of fermentation process. Czech Journal of Animal Science 50:553-560.

Ellis, J.L., Hindrichsen, I.K., Klop, G., Kinley, R.D., Milora, N., Bannink, A., et al. 2016. Effects of lactic acid bacteria silage inoculation on methane emission and productivity of Holstein Friesian dairy cattle. Journal of Dairy Science 99:7159-7174.

Ertl, P., Zebeli, Q., Zollitsch, W., and Knaus, W. 2015. Feeding of by-products completely replaced cereals and pulses in dairy cows and enhanced edible feed conversion ratio. Journal of Dairy Science 98:1225-1233.

Ferguson, J.D., Galligan, D.T., and Thomsen, N. 1994. Principal descriptors of body condition score in Holstein cows. Journal of Dairy Science 77:2695-2703

Flythe, M.D., and Russell, J.B. 2004. The effect of pH and a bacteriocin (bovicin HC5) on Clostridium sporogenes MD1, a bacterium that has the ability to degrade amino acids in ensiled plant materials. FEMS Microbiology Ecology 47:215-222.

Goering, H., and Van Soest, P.J. 1970. Forage fiber analysis (apparatus, reagents, procedures, and some applications). United States Department of Agriculture, Washington, D.C., USA.

Gregorini, P. 2012. Diurnal grazing pattern: its physiological basis and strategic management. Animal Production Science 52:416-430.

Hall, M.B., Nennich, T.D., Doane, P.H., and Brink, G.E. 2015. Total volatile fatty acid concentrations are unreliable estimators of treatment effects on ruminal fermentation in vivo. Journal of Dairy Science 98:3988-3999.

Kara, K. 2019. The in vitro digestion of neutral detergent fibre and other ruminal fermentation parameters of some fibrous feedstuffs in Damascus goat (Capra aegagrus hircus). Journal of Animal and Feed Sciences 28:159-168.

Kung Jr., L., and Muck, R.E. 1997. Effects of silage additives ensiling. Proceedings from the Silage: Field to Feedbunk North American Conference, Hershey. 11-13 February. NRAES-99. p. 187-199. Natural Resource, Agriculture, and Engineering Service (NRAES), Ithaca, New York, USA.

Loucka, R. 2012. The effect of chemical additive on the quality of sugar beet pulp silage. Listy Cukrovarnické a Reparské (Czech Sugar and Sugar Beet Journal) 128:30-33.

Mattiauda, D.A., Tamminga, S., Gibb, M.J., Soca, P., Bentancur, O., and Chilibroste, P. 2013. Restricting access time at pasture and time of grazing allocation for Holstein dairy cows: Ingestive behaviour, dry matter intake and milk production. Livestock Science 152:53-62.

Michel, F., Thibault, J.-F., Barry, J.-L., and de Baynast, R. 1988. Preparation and characterisation of dietary fibre from sugar beet pulp. Journal of the Science of Food and Agriculture 42:77-85.

Muck, R.E., Nadeau, E.M.G., McAllister, T.A., Contreras-Govea, F.E., Santos, M.C., and Kung, L. 2018. Silage review: Recent advances and future uses of silage additives. Journal of Dairy Science 101:3980-4000.

Münnich, M., Khiaosa-ard, R., Klevenhusen, F., Hilpold, A., Khol-Parisini, A., and Zebeli, Q. 2017. A meta-analysis of feeding sugar beet pulp in dairy cows: Effects on feed intake, ruminal fermentation, performance, and net food production. Animal Feed Science and Technology 224:78-89.

Oliveira, A.S., Weinberg, Z.G., Ogunade, I.M., Cervantes, A.A.P., Arriola, K.G., Jiang, Y., et al. 2017. Meta-analysis of effects of inoculation with homofermentative and facultative heterofermentative lactic acid bacteria on silage fermentation, aerobic stability, and the performance of dairy cows. Journal of Dairy Science 100:4587-4603. 
Pahlow, G., Muck, R., Driehuis, F., Elferink, S., and Spoelstra, S. 2003. Microbiology of ensiling. In Buxton, D., Muck, R., and Harrison, J. (eds.) Silage science and technology. American Society of Agronomy, Crop Science Society of America, Soil Science Society of America, Madison, Wisconsin, USA.

Peyraud, J.L., and Delagarde, R. 2011. Managing variations in dairy cow nutrient supply under grazing. Animal 7:57-67.

Rodriguez, I. 2014. A review on the effects of mycotoxins in dairy ruminants. Animal Production Science 54:1155-1165.

Ruiz-Albarrán, M., Balocchi, O.A., Noro, M., Wittwer, F., and Pulido, R.G. 2016. Effect of the type of silage on milk yield, intake and rumen metabolism of dairy cows grazing swards with low herbage mass. Animal Science Journal 87:878-884. doi:10.1111/asj.12513.

Seymour, W.M., Campbell, D.R., and Johnson, Z.B. 2005. Relationships between rumen volatile fatty acid concentrations and milk production in dairy cows: a literature study. Animal Feed Science and Technology 119:155-169.

Tavendale, M.H., Meagher, L.P., Pacheco, D., Walker, N., Attwood, G.T., and Sivakumaran, S. 2005. Methane production from in vitro rumen incubations with Lotus pedunculatus and Medicago sativa, and effects of extractable condensed tannin fractions on methanogenesis. Animal Feed Science and Technology 123-124:403-419.

Tilley, J.M.A., and Terry, R.A. 1963. A two-stage technique for the in vitro digestion of forage crops. Grass and Forage Science 18:104-111.

Van Soest, P.J., Robertson, J.B., and Lewis, B.A. 1991. Methods for dietary fiber, neutral detergent fiber, and nonstarch polysaccharides in relation to animal nutrition. Journal of Dairy Science 74:3583-3597.

Weber, U., Kaiser, E., und Steinhöfel, O. 2003. Untersuchungen zur Silierung von Zuckerrü benpressschnitzeln in Folienschläuchen. Part 1: Einfluss einer verzö gerten Einsilierung (24 Stunden Zwischenlagerung) auf Futterwert, Verluste und Silagequalität; Kosten der Schlauchsilierung. Sugar Industry 131:691-697.

Weinberg, Z.G., and Muck, R.E. 1996. New trends and opportunities in the development and use of inoculants for silage. FEMS Microbiology Reviews 19:53-68.

Weinberg, Z.G., Muck, R.E., and Weimer, P.J. 2003. The survival of silage inoculant lactic acid bacteria in rumen fluid. Journal of Applied Microbiology 94:1066-1071.

Wyss, U., Metthez, C., and Arrigo, Y. 2015. Silage quality: pressed sugar-beet pulp with added molasses. Agrarforschung Schweiz 6:416-423. 